\title{
Identifikasi Struktur Bawah Permukaan Geologi Karangsambung Terhadap Terobosan Dyke dan Sill Menggunakan Metode Gaya Berat
}

\author{
Lorensiana Ristaa, Okto Ivansyah ${ }^{\mathrm{b} *}$, Riza Adriat ${ }^{\mathrm{a}}$
}

\author{
aProdi Geofisika, FMIPA Universitas Tanjungpura, Jalan Prof. Dr. Hadari Nawawi, Pontianak, Indonesia \\ bPoliteknik Negeri Pontianak, Jalan Ahmad Yani, Pontianak, Indonesia \\ *Email : oktoivansyah@yahoo.com
}

\begin{abstract}
Abstrak
Telah dilakukan penelitian tentang identifikasi struktur geologi daerah Karangsambung berdasarkan pengolahan data nilai gaya berat. Penelitian ini bertujuan untuk mengetahui gambaran struktur geologi bawah permukaan terhadap terobosan dyke dan sill. Hal ini terkait wilayah Karangsambung yang memiliki geologi kompleks yang memiliki peran sangat penting dalam ilmu kebumian terutama dapat dijadikan sebagai tempat pelatihan maupun penelitian geologi. Pada bidang geofisika metode gaya berat digunakan untuk memodelkan struktur bawah permukaan berdasarkan variasi densitas batuan di bawah permukaan. Nilai anomali gaya berat yang diinterpretasikan adalah nilai anomali gaya berat residual hasil upward continuation. Nilai densitas rata-rata yang digunakan adalah 2,76 g/ $\mathrm{cm}^{3}$, diperoleh dari nilai densitas rata-rata batuan asal yang terdapat di daerah Karangsambung. Dari pemodelan struktur bawah permukaan menggunakan software Grav2dc, diperoleh struktur yang diduga sebagai dyke dengan jenis batuan basal $\left(3,03 \mathrm{~g} / \mathrm{cm}^{3}\right)$ pada lintasan $\mathrm{AA}_{1}$ dan pada lintasan $\mathrm{BB}_{1}$ diperoleh struktur yang diduga sebagai dyke dengan jenis batuan andesit $\left(2,54 \mathrm{~g} / \mathrm{cm}^{3}\right)$.
\end{abstract}

Kata Kunci : Metode gaya berat, Karangsambung, Dyke dan sill

\section{Latar Belakang}

Wilayah Karangsambung ditetapkan sebagai Kawasan Cagar Alam Geologi Karangsambung (KCAGK) berdasarkan Surat Keputusan Menteri Energi dan Sumber Daya Mineral Republik Indonesia Nomor : 2817 K/40/MEM/2006 pada tanggal 10 November tahun 2006 [4]. Kawasan Karangsambung menjadi tempat yang sangat penting untuk ilmu kebumian terutama dapat dijadikan tempat penelitian maupun pelatihan geologi karena memiliki keunikan geologi kompleks yang menyimpan beragam jenis batuan beku, sedimen, dan metamorf. Karangsambung merupakan rekaman evolusi pergerakan lempeng bumi pada masa lampau sekitar 60 juta tahun yang lalu [3]. Akibat peristiwa tersebut, diduga mengindikasikan batuan hasil tumbukan membuat terobosan pada tubuh batuan beku di bawah permukaan.

Sebelumnya, Subagio (2008) telah melakukan kajian pada wilayah Kebumen. Penelitian tersebut mengkaji tentang struktur geologi bawah permukaan daerah Kebumen berdasarkan analisis pola anomali gaya berat dan magnetik dan diketahuilah struktur geologi yang terekam pada pola anomali bouguer adalah ditemukannya sesar normal di Karanggayam, tubuh batuan intrusi andesit tersingkap di daerah Karang-bolong dan Kulon Progo dengan kedalaman kurang lebih 17 km. Nilai anomali di
Komplek Luk Ulo (114 mGal) relatif lebih rendah karena intrusi andesit (145 mGal).

Penelitian struktur geologi di daerah Karangsambung perlu dilakukan dikarenakan wilayah tersebut diduga memiliki gambaran struktur bawah permukaan berupa terobosan dyke dan sill yang berguna untuk mengetahui struktur geologi daerah. Oleh karena itu, diperlukan upaya dalam penyelidikan bawah permukaan untuk mengetahui jenis terobosan batuan yang teridentifikasi pada wilayah Karangsambung berdasarkan kedudukan batuan terhadap perlapisannya, dan berfokus pada terobosan dyke dan sill menggunakan salah satu metode geofisika, yaitu metode gaya berat. Metode gaya berat dapat digunakan untuk pemodelan struktur geologi bawah permukaan yang kemudian akan dijadikan acuan untuk melakukan interpretasi. Interpretasi yang dilakukan ini, diharapkan dapat memberikan informasi dan gambaran tentang kondisi geologi bawah permukaan terhadap terobosan dyke dan sill di wilayah Karangsambung.

\section{Metodologi}

2.1 Lokasi Penelitian

Penelitian dilakukan pada wilayah Karang-sambung, Kebumen Jawa Tengah. Secara geografis, Karangsambung terletak pada koordinat 109'37'30" - 109 45'00" BT dan 7॰30’00" - 7॰37’30” LS (Gambar 1). 


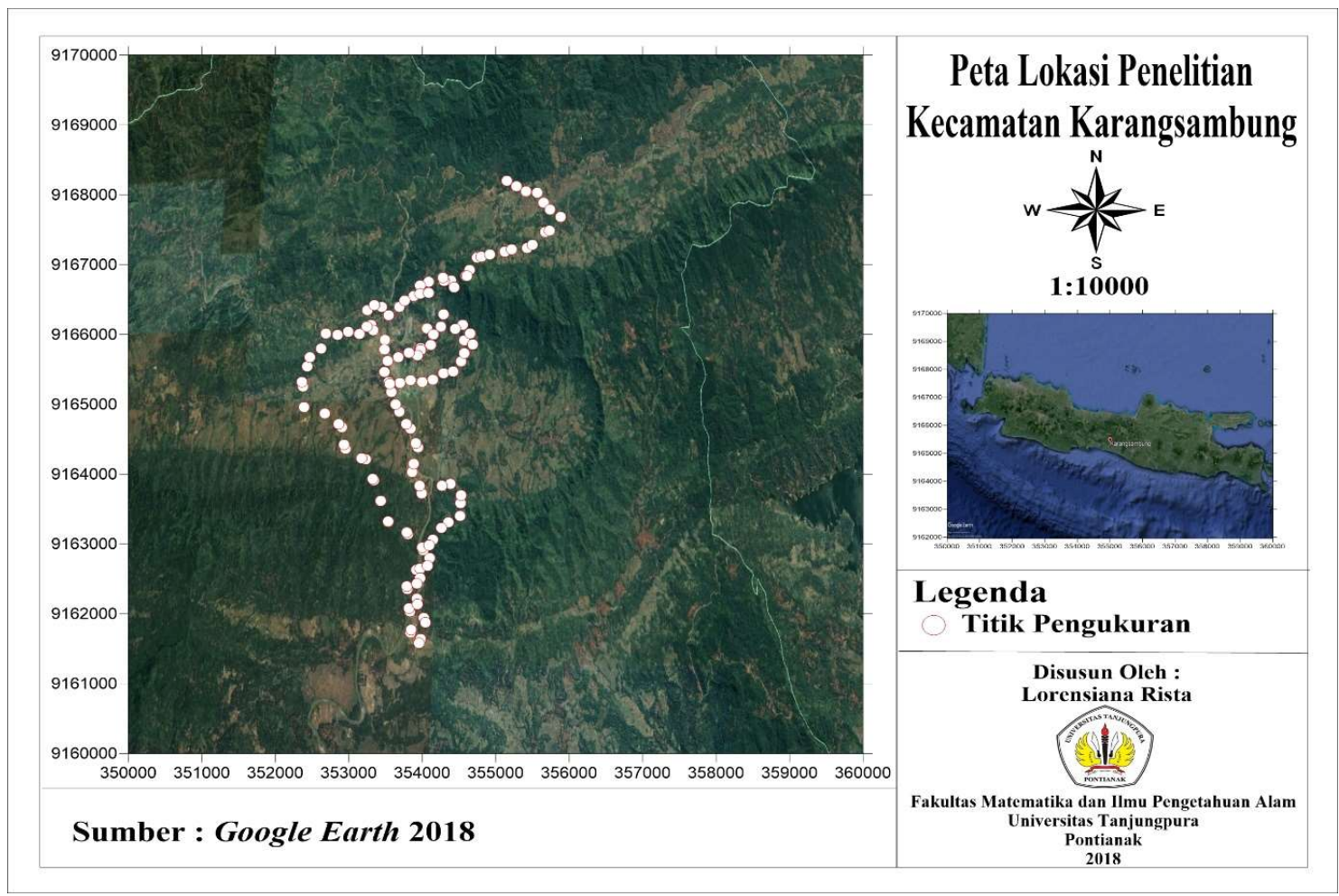

Gambar 1. Peta lokasi penelitian

\subsection{Pengolahan Data}

Data yang digunakan dalam penelitian ini merupakan data sekunder meliputi nilai bacaan (mGal) dari alat gravitimeter pada metode gaya berat, waktu pengukuran, dan elevasi yang diambil pada tahun 2012 .

Langkah-langkah yang digunakan untuk menyelesaikan masalah dan memenuhi tujuan dari penelitian ini adalah :

1. Studi literatur mengenai wilayah penelitian yang berkaitan dengan struktur geologi daerah dan geofisika.

2. Mengolah nilai Complete Bouguer Anomaly (CBA) untuk mendapatkan peta CBA, anomali regional dan residual daerah penelitian.

3. Mengolah data peta CBA menjadi nilai Upward Continuation dengan mengkorelasikan dengan anomali residual.

4. Menentukan dan menganalisa daerah yang diduga terdapat struktur geologi bawah permukaan dyke dan sill menggunakan nilai Upward Continuation yang berkorelasi dengan nilai anomali residual dengan membuat slicing (penyayatan).

5. Mengidentifikasi dan menganalisa struktur geologi bawah permukaan yang diduga terdapat struktur geologi dyke dan sill yang telah di-slicing berdasarkan hasil interpretasi dan analisis peta Upward Continuation terhadap anomali residual.

\subsection{Diagram Alir}

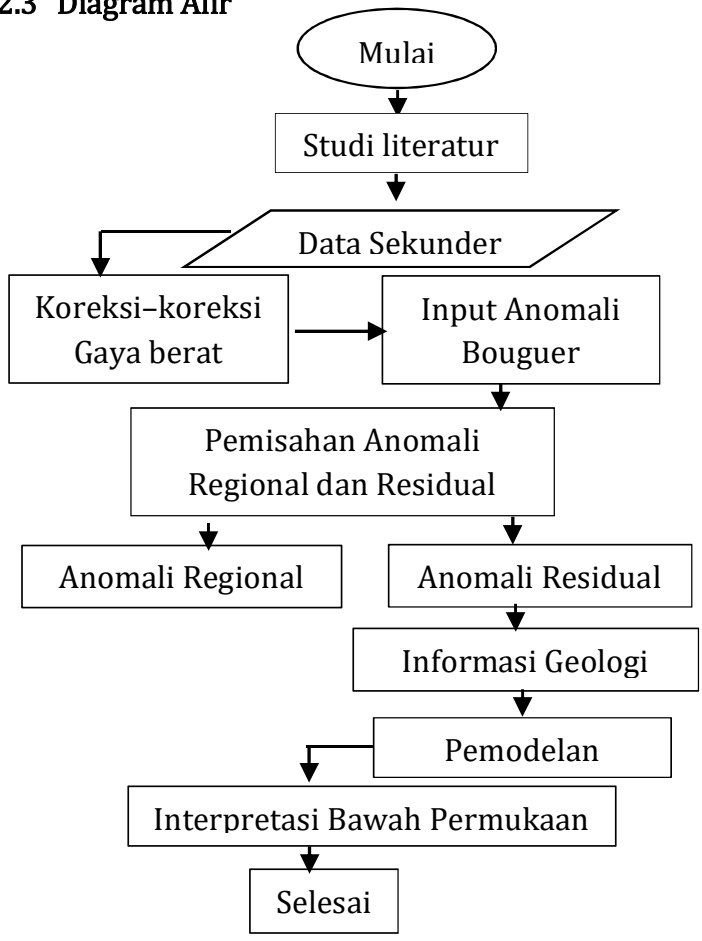

Gambar 2. Diagram Alir 


\section{Hasil dan Pembahasan}

Prinsip utama dalam metode gaya berat adalah variasi medan gravitasi bumi yang disebabkan oleh perbedaan densitas antar batuan di bawah permukaan yang berguna untuk menggambarkan struktur geologi di bawah permukaan bumi. Pada bagian hasil dan pembahasan ini akan dibahas mengenai hasil pengolahan data dengan mengacu pada batasan masalah dari penelitian yang telah dilakukan ini, dan kemudian akan diinterpretasi lebih lanjut untuk mengetahui struktur bawah permukaan sesuai dengan tujuan penelitian ini.

\subsection{Complete Bouguer Anomaly (CBA)}

Complete Bouguer Anomaly merupakan anomali gaya berat yang digunakan sebagai dasar pendugaan struktur bawah permukaan. Dari peta pola CBA dapat diketahui daerah yang memiliki nilai anomali terendah sampai tertinggi berdasarkan distribusi warna pada peta tersebut.

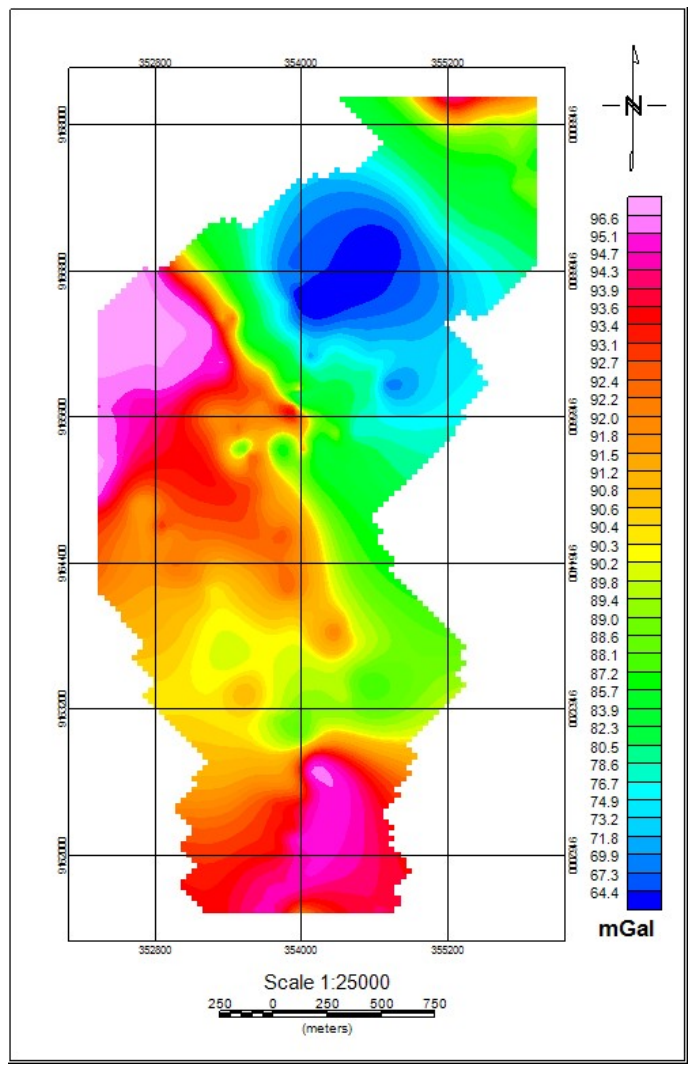

Gambar 3. Peta pola Complete Bouguer Anomaly (CBA)

\subsection{Pemisahan Anomali Regional-Residual}

Anomali regional-residual diperoleh dari nilai anomali Bouguer. Anomali Bouguer yang terbaca masih dipengaruhi oleh nilai anomali dalam dan anomali dangkal sebagai akibat koreksi-koreksi gaya berat yang telah dilakukan sebelumnya. Anomali Bouguer yang telah dikoreksi tersebut merupakan respon anomali yang berasal dari material bawah permukaan. Oleh karena itu, perlu dilakukan pemisahan anomali regional-residual untuk mengetahui nilai anomali khususnya anomali residual (Gambar 4). Hal itu dilakukan karena pengukuran berada di kerak bumi di wilayah dangkal.

\subsubsection{Anomali Regional}

Gambar 4 menunjukkan pola anomali regional yang telah dilakukan Upward Continuation untuk mengetahui kondisi geologi umum di daerah Karangsambung. Gambar 4 menunjukkan pola penyebaran anomali regional tinggi terdapat pada 3 arah yaitu anomali rendah berbentuk circular (bundar) pada arah Utara dengan nilai anomali 70,7 hingga 77,7 mGal ditandai oleh warna biru tua hingga biru muda, anomali regional sedang berada pada 2 arah, yaitu dari Tenggara dan Barat Laut dengan nilai anomali sebesar 77,7 hingga 89,2 mGal ditandai oleh warna hijau hingga jingga, sedangkan pada arah Barat-Barat Laut dan arah Selatan dengan anomali terdapat anomali tinggi sebesar 92,2 sampai 97,1 mGal ditandai warna merah hingga merah muda.

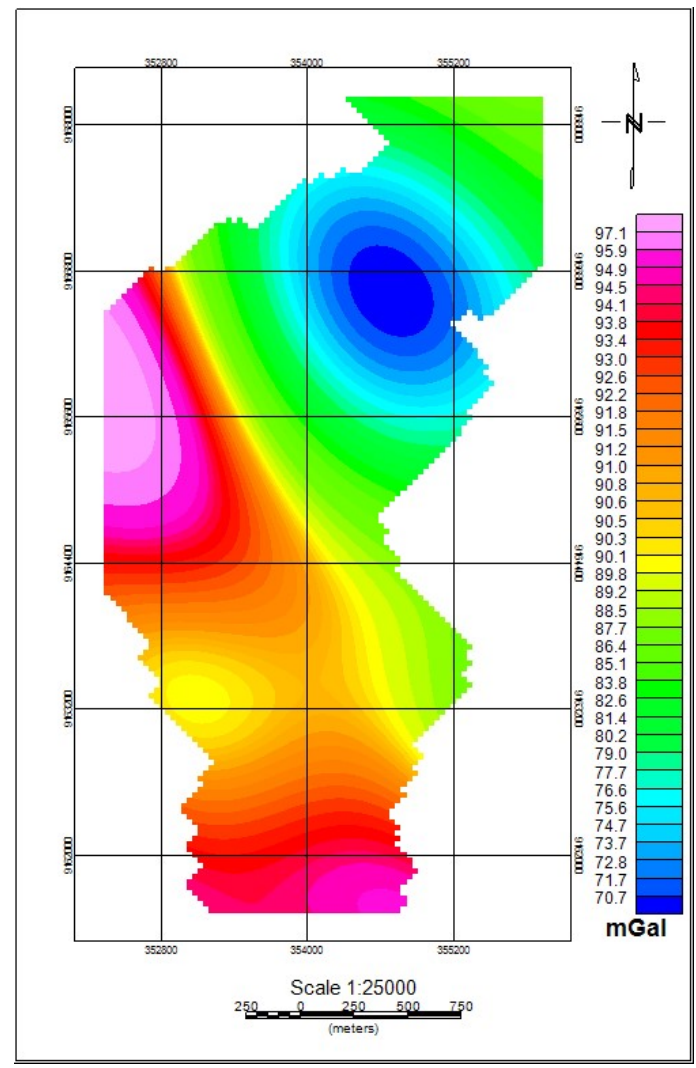

Gambar 4. Peta anomali regional 


\subsubsection{Anomali Residual}

Gambar 5 menunjukkan pola penyebaran anomali residual di wilayah Karangsambung. Dari anomali residual ini selanjutnya dapat dilakukan interpretasi terhadap kondisi geologi bawah permukaan. Nilai anomali residual yang didapat berkisar antara -7,2 sampai 7,4 mGal yang menunjukkan pola anomali negatif hingga positif. Anomali negatif ditunjukkan oleh warna biru tua hingga kuning dengan kisaran nilai anomali $-7,2$ sampai $-0,1 \mathrm{mGal}$, sedangkan anomali positif ditunjukkan oleh warna jingga hingga merah muda dengan kisaran nilai anomali 0,1 sampai $6,4 \mathrm{mGal}$.

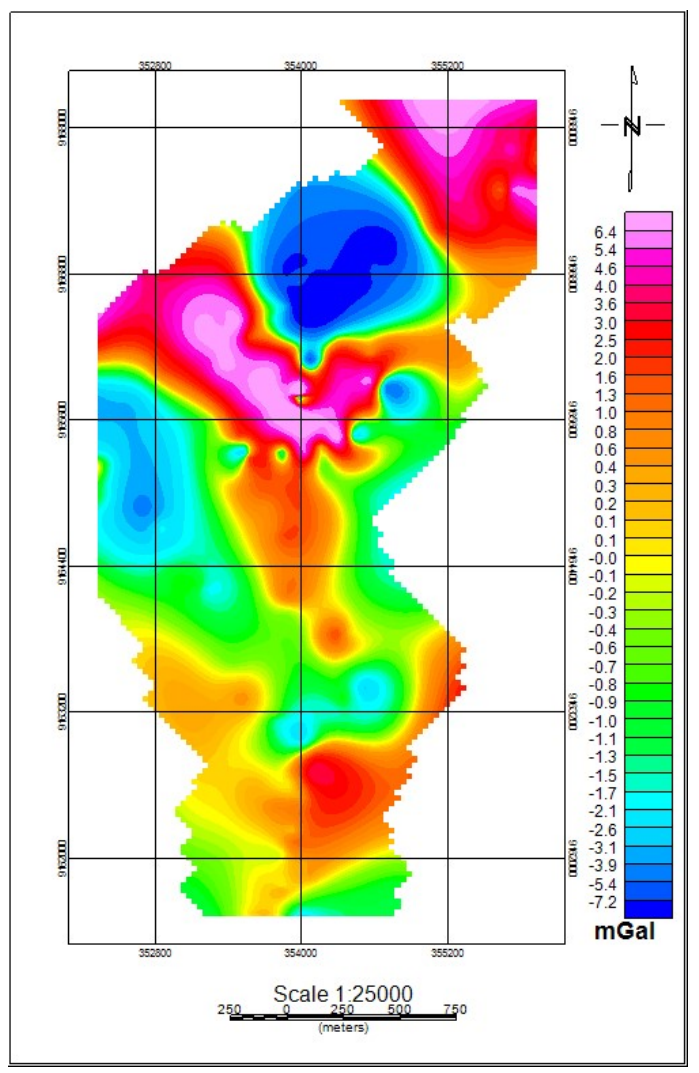

Gambar 5. Peta anomali residual

\subsection{Upward Continuation dari Anomali Residual}

Upward Continuation dilakukan untuk mendapatkan hasil berupa anomali regional yang lebih representatif. Hal tersebut bertujuan untuk menghasilkan anomali residual yang baik, sehingga pada tahap interpretasi dapat menghasilkan hasil yang baik pula. Upward Continuation digunakan sebagai filter yang berguna untuk menghilangkan noise akibat benda-benda dekat permukaan, dengan kata lain Upward Continuation dapat juga digunakan ntuk mengurangi efek dari sumber anomali residual.
Gambar 6 memperlihatkan pola Upward Continuation dari anomali residual. Pola ini menunjukkan kelompok anomali negatif dan positif. Anomali negatif ditandai dengan warna hijau muda sampai biru tua, sedangkan anomali positif ditandai oleh warna merah muda hingga warna kuning. Anomali negatif kisaran nilainya berkisar antara -2,0 sampai -0,2 mGal dan anomali positif memiliki kisaran nilai 0 sampai 3 mGal.

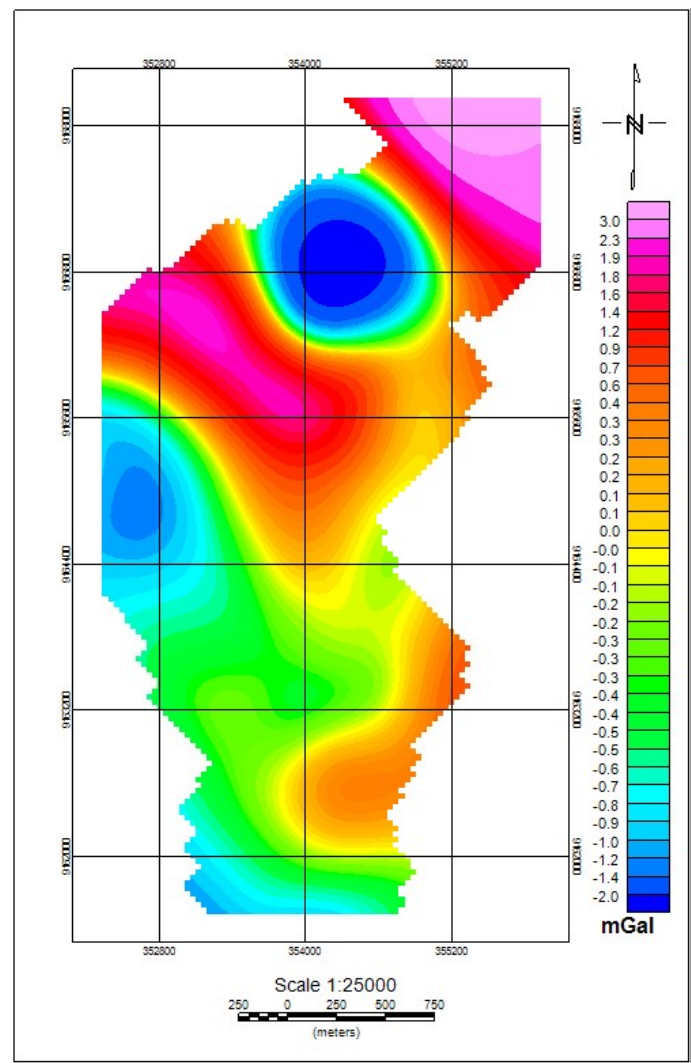

Gambar 6. Peta Upward Continuation dari anomali residual

\subsubsection{Peta Geologi dan Upward Continuation dalam tahap Slicing}

Arah Utara pada koordinat X 354500 Y 9166500 terlihat pola anomali negatif yang cukup rendah dibandingkan dengan anomali positif. Hal ini menjadi dugaan awal, bahwa di wilayah tersebut terdapat struktur intrusi batuan beku dyke dan sill di bawah permukaan.

Gambar 7 merupakan gabungan antara peta geologi daerah penelitian dan peta pola Upward Continuation pada anomali residual yang telah dilakukan tahap slicing (penyayatan). Tahap slicing dilakukan bertujuan untuk mengetahui bentuk struktur bawah permukaan dari hasil pengolahan data. Peta geologi turut ditampilkan bertujuan untuk memberikan informasi pendukung sebagai acuan dasar dari informasi geologi daerah tersebut. 
Slicing dilakukan pada kedua lintasan tersebut berdasarkan penyebaran pola Upward Continuation dengan kontras nilai anomali yang relatif turun-naik (positif-negatif). Nilai anomali di lintasan $\mathrm{AA}_{1}$ diawali pada anomali positif ditunjukkan dengan warna merah dan menurun drastis menuju anomali negatif ditunjukkan dengan warna violet. Sedangkan lintasan $\mathrm{BB}_{1}$ dimulai dari anomali negatif, di pertengahan lintasan berada pada anomali sedang yang ditunjukkan dengan warna hijau dan biru hingga kembali pada anomali negatif.

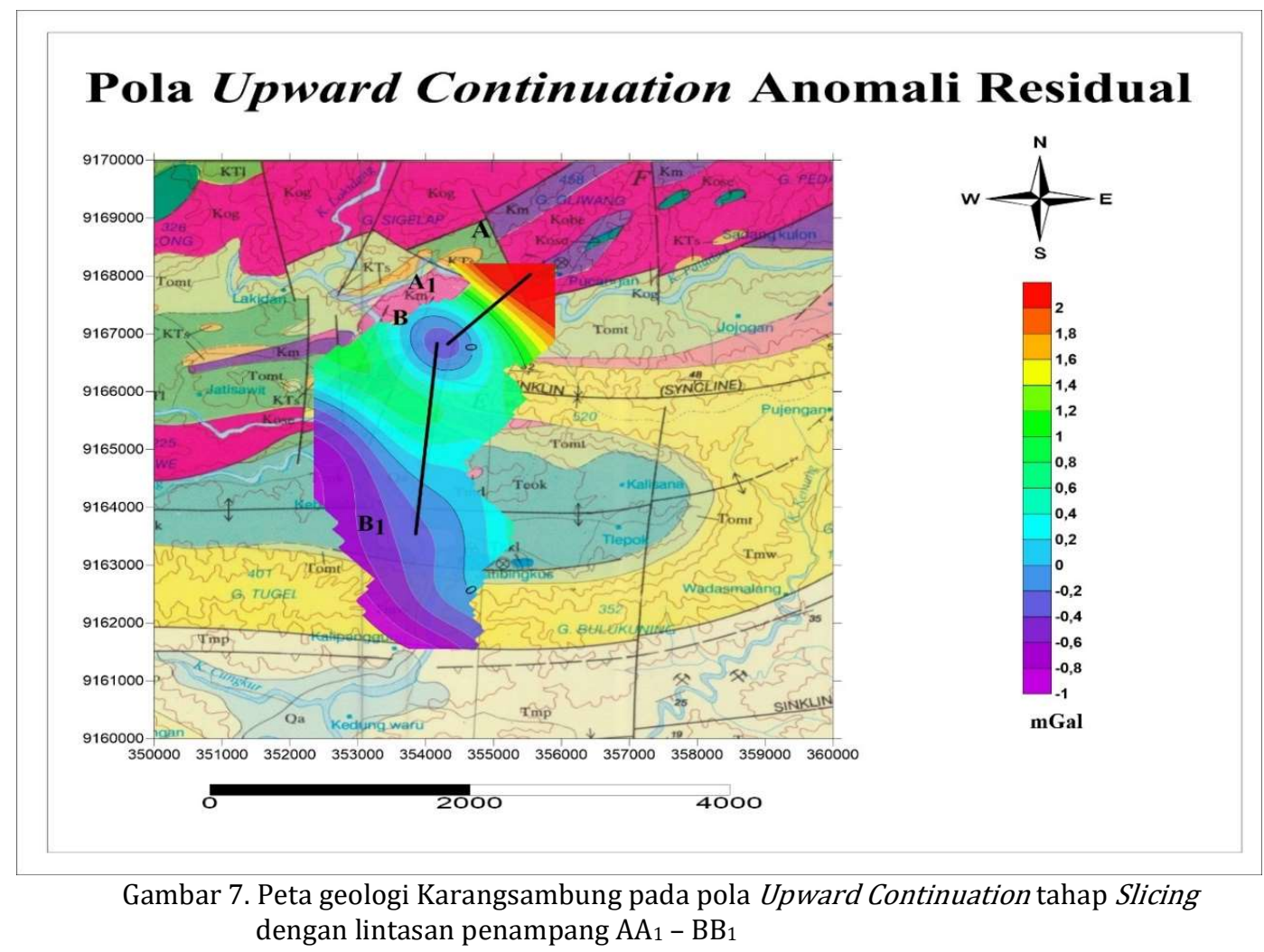

3.3.2 Penampang Pemodelan Lintasan $\mathrm{AA}_{1}$ (Timur Laut - Barat Daya)

Lintasan penampang pada Gambar 7 dibuat untuk mengetahui geometri dari intrusi dyke dan sill pada penampang $\mathrm{AA}_{1}$. Lintasan $\mathrm{AA}_{1}$ (Timur Laut - Barat Daya) memperlihatkan pada peta pola Upward Continuation (Gambar 6) memiliki perubahan nilai anomali positif ke negatif.

Berdasarkan pengamatan, terlihat kontras nilai anomali lintasan $\mathrm{AA}_{1}$ (Timur Laut Barat Daya) menunjukkan tinggginya nilai anomali di bagian A arah Timur Laut, diduga akibat terobosan batuan intrusi basal $(\rho=3,03$ $\mathrm{g} / \mathrm{cm}^{3}$ ) berstruktur dyke dan berasosiasi dengan batuan beku andesit $\left(\rho=2,53 \mathrm{~g} / \mathrm{cm}^{3}\right)$ serta batuan metamorf sepertinit $\left(\rho=2,75 \mathrm{~g} / \mathrm{cm}^{3}\right)$ yang berada di lapisan atas berupa lapisan tipis. Kemudian pada bagian $A_{1}$ arah Barat Daya nilai anomali semakin turun menuju nilai anomali negatif. Hal ini diduga diakibatkan adanya tiga jenis struktur batuan yang teridentifikasi pada pemodelan struktur bawah permukaan tersebut, antara lain ditafsirkan sebagai batuan beku gabro $\left(\rho=2,90 \mathrm{~g} / \mathrm{cm}^{3}\right)$, formasi Totogan ( $\rho=$ $2,67 \mathrm{~g} / \mathrm{cm}^{3}$ ) yang berada di atas gabro, serta teridentifikasinya struktur yang diduga sebagai Komplek Lok Ulo $\left(\rho=2,85 \mathrm{~g} / \mathrm{cm}^{3}\right)$. Formasi Totogan terdiri dari campuran breksi dengan komponen batu lempung, batu pasir, batu gamping, dan basal. Sedangkan Komplek Lok Ulo terdiri dari berbagai macam bongkah yang tercampur secara tektonik dalam masa dasar serpih hitam. 


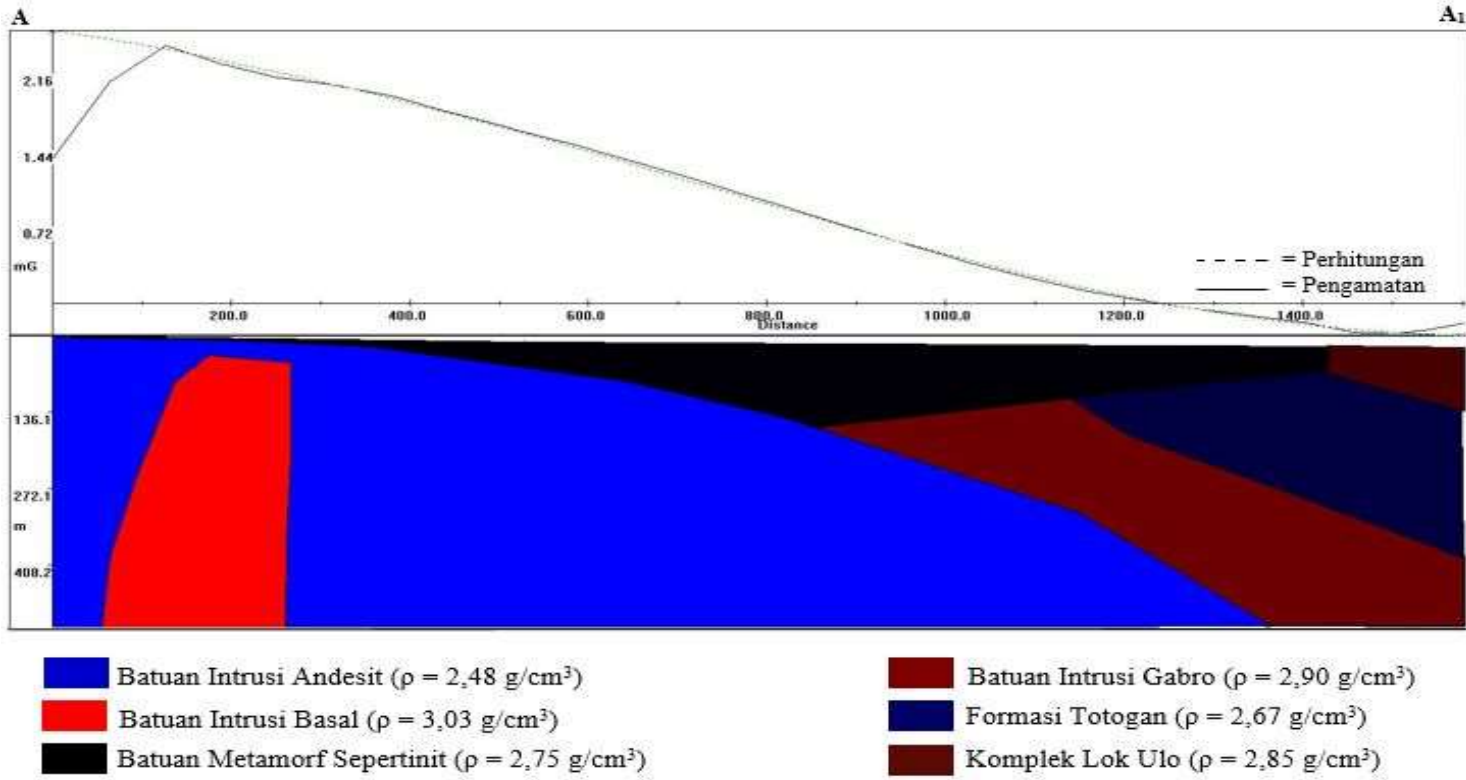

Gambar 8. Penampang pemodelan Anomali Bouguer lintasan AA 1 (Timur Laut - Barat Daya)

3.3.3 Penampang Pemodelan Lintasan $\mathrm{BB}_{1}$ (Utara - Selatan)

Penampang pemodelan lintasan $\mathrm{BB}_{1}$

(Utara - Selatan) pada Gambar 8 memperlihatkan grafik nilai anomali diawali dengan anomali negatif, hal ini diduga akibat terdapat jenis struktur batuan yang ditafsirkan sebagai Komplek Lok Ulo $\left(\rho=2,85 \mathrm{~g} / \mathrm{cm}^{3}\right)$ dengan bentuk struktur memanjang mulai dari Utara sampai ke Selatan. Pada jarak 1000 meter terjadi peningkatan anomali menjadi anomali positif, diduga akibat jenis batuan yang ditafsirkan sebagai struktur batuan beku basal $\left(\rho=3,03 \mathrm{~g} / \mathrm{cm}^{3}\right)$ dan teridentifikasi pula suatu terobosan batuan berstrukur $d y k e$ dengan jenis batuan intrusi andesit $\left(\rho=2,48 \mathrm{~g} / \mathrm{cm}^{3}\right)$. Kemudian, pada lintasan penampang tersebut terdapat struktur batuan yang ditafsirkan sebagai batuan beku diabas $\left(\rho=2,78 \mathrm{~g} / \mathrm{cm}^{3}\right)$ dengan struktur batuan memanjang dengan kedalaman sekitar 300 meter di bawah permukaan. Pada jarak 2000 - 3000 meter, grafik menurun kembali ke anomali negatif. Rendahnya nilai anomali densitas pada jarak ini disebabkan oleh tebalnya lapisan struktur batuan sedimen breksi $\left(\rho=2,70 \mathrm{~g} / \mathrm{cm}^{3}\right)$ dan lapisan batuan metamorf sekis $\left(\rho=2,76 \mathrm{~g} / \mathrm{cm}^{3}\right)$ di lapisan atasnya, serta lapisan Komplek Lok Ulo.

B

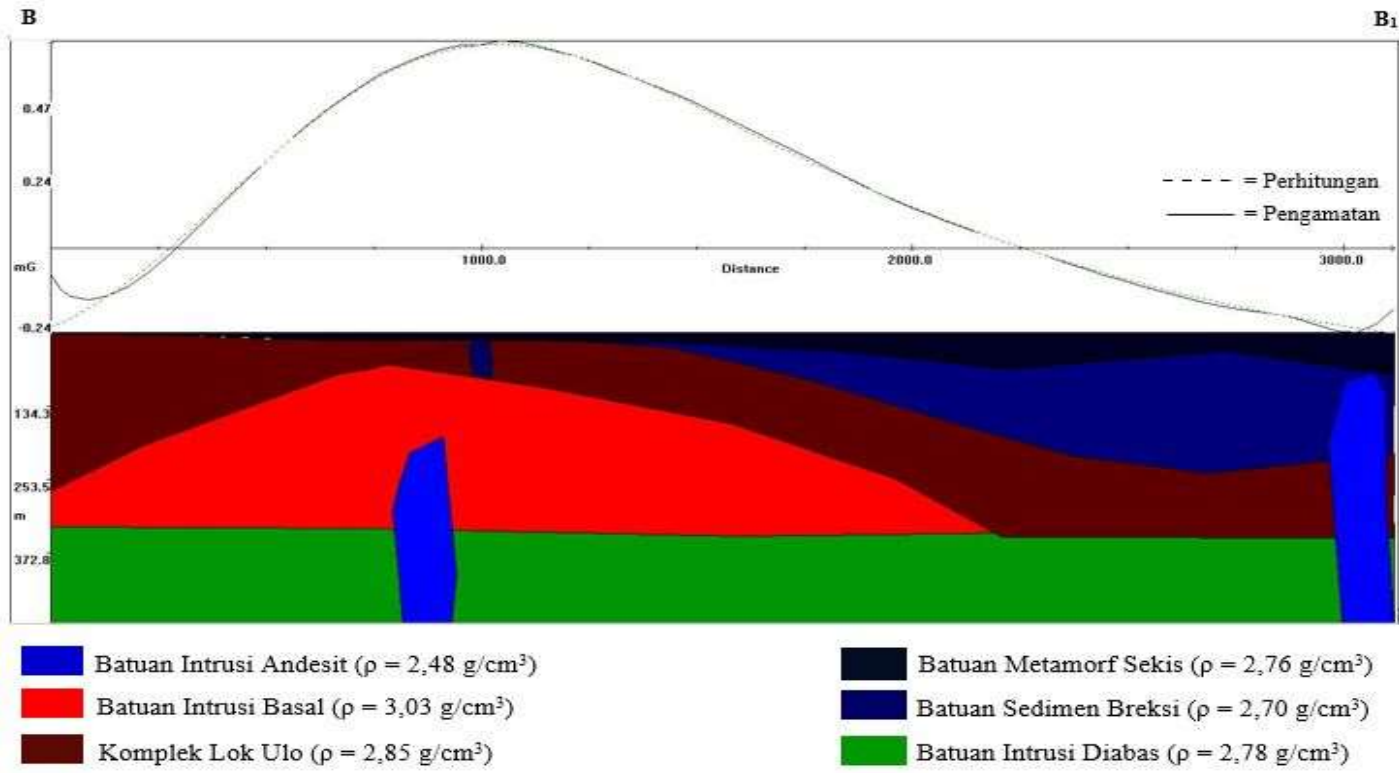

Gambar 9. Penampang pemodelan Anomali Bouguer lintasan $\mathrm{BB}_{1}$ (Utara- Selatan) 


\section{Kesimpulan}

Berdasarkan pemodelan yang telah dilakukan, dapat disimpulkan bahwa pada pemodelan gaya berat ini, diduga sebagai terobosan dyke di peta slicing lintasan penampang $\mathrm{AA}_{1}$ berupa intrusi batuan beku basal $\left(\rho=3,03 \mathrm{~g} / \mathrm{cm}^{3}\right)$ dan lintasan penampang $\mathrm{BB}_{1}$ intrusi batuan andesit berupa $(\rho=2,48$ $\mathrm{g} / \mathrm{cm}^{3}$ ), serta tidak teridentifikasinya terobosan sill.

\section{Daftar Pustaka}

[1] Google Earth. (2018, Agustus 08). Diambil kembali dari http://www.earthgoogle.com

[2] Noor, D. (2009). Pengantar Geologi. Bogor: CV. Ilmu Graha.

[3] Nur, A. M. (2014). Sungai Meander Luk Ulo Antara Kondisi Ideal dan Kenyataan. Jurnal Geografi, 217 - 226.

[4] Raharjo, P. D., \& Nur, A. M. (2013). Pemetaan Gerakan Tanah Kawasan Cagar Alam Geologi Karangsambung dengan Menggunakan Data Penginderaan Jauh dan SIG. Forum Geografi, Vol. 27, No. 2, 99 - 114.

[5] Subagio. (2008). Struktur Geologi Bawah Permukaan Daerah Kebumen Berdasarkan Analisis Pola Anomali Gaya Berat dan Geomagnet. Geo-Sciences JSDG Vol. 18, 391 407. 